\title{
Germline mutation analysis of Tpit in Poodle dogs with ACTH-dependent hyperadrenocorticism
}

\author{
[Análise de mutação germinativa do Tpit em cães da raça Poodle com hiperadrenocorticismo \\ ACTH-dependente] \\ V. De Marco ${ }^{1,2,3}$, L.R. Carvalho ${ }^{1}$, A.E.C. Billerbeck ${ }^{1}$, B.B. Mendonça ${ }^{1}$ \\ ${ }^{1}$ Faculdade de Medicina - Universidade de São Paulo, São Paulo, SP \\ ${ }^{2}$ Faculdade de Medicina Veterinária - UNISA - São Paulo, SP \\ ${ }^{3}$ NAYA Especialidades Veterinárias - São Paulo, SP
}

\begin{abstract}
There is a high incidence of pituitary-dependent hyperadrenocorticism (PDH) in Poodle dogs, with family members being affected by the disease, suggesting a genetic involvement. Tpit is an obligate transcription factor for the expression of pro-opiomelanocortingene and for corticotroph terminal differentiation. The aim of the present study was to screen the Tpit gene for germline mutations in Poodles with PDH. Fifty Poodle dogs (33 female, 8.71 \pm 2.8 years) with PDH and 50 healthy Poodle dogs (32 females, 9.42412 .8 years) were studied. Genomic DNA was isolated from peripheral blood, amplified by PCR and submitted to automatic sequence. No mutation in the coding region of Tpit was found, whereas the new single nucleotide polymorphism p.S343G, in heterozygous state, was found in the same frequency in both PDH and control groups. We concluded that Tpit gain-of-function mutations are not involved in the etiology of $\mathrm{PDH}$ in Poodle dogs.
\end{abstract}

Keywords: dog, ACTH-dependent hyperadrenocorticism, Tpit, mutation

\section{RESUMO}

O hiperadrenocorticismo ACTH-dependente (HACAD) apresenta elevada incidência em cães da raça Poodle, sendo que membros da mesma família têm sido acometidos pela doença, sugerindo envolvimento genético. Tpit é um fator de transcrição obrigatório para a expressão do gene da pro-opiomelanocortina e para a diferenciação terminal dos corticotrofos. O objetivo deste trabalho foi pesquisar mutações germinativas no gene Tpit em Poodles com HACAD. Cinquenta cães da raça Poodle, 33 fêmeas, média de idade de 8,71+2,8 anos, com HACAD, e 50 cães Poodles saudáveis, 32 fêmeas, média de idade de 9,4+2,8 anos, foram estudados. Mutações na região codificadora do gene Tpit não foram identificadas. Foi observado um novo polimorfismo em heterozigose, p.S343G, com a mesma frequência no grupo de cães com HACAD e no grupo-controle. Conclui-se que a mutação ativadora no gene Tpit não está envolvida na patogênese do hiperadrenocorticismo ACTH-dependente em cães da raça Poodle.

Palavras-chave: cão, hiperadrenocorticismo ACTH-dependente, Tpit, mutação

\section{INTRODUCTION}

Cushing's syndrome is a very common endocrinopathy in dogs, characterized by chronic exposure to hypercortisolism leading to a classic phenotype characterized by polydipsia, polyuria, polyphagia, abdominal enlargement, alopecia, pyoderma, panting and muscle weakness
(Behrend and Kemppainen, 2001; Feldman and Nelson, 2004; Peterson, 2007). ACTH-dependent hyperadrenocorticism (ADHAC) is the most common cause of naturally occurring hypercortisolism in dogs, accounting for 80 to $85 \%$ of cases (Peterson et al., 1982; Behrend and Kemppainen, 2001; Peterson, 2001; Peterson, 2007). ADHAC mainly affects dogs older than 6 years with no sexual predisposition

Recebido em 26 de novembro de 2011

Aceito em 24 de maio de 2012

E-mail: vivianidemarco@terra.com.br 
(Guptill et al., 1997; Feldman and Nelson, 2004). Poodle, Dachshunds, Beagles, various Terrier breeds and Boxers appear to be at great risk of developing hyperadrenocorticism (HAC) (Behrend et al., 2002; Feldman and Nelson 2004; Peterson, 2007).

Several putative transcription-regulating proteins have been identified in the adenohypophysis and have been implicated as key elements in the definition of cell-specific phenotypes and the regulation of hormone gene expression (Asa and Ezzat, 1998). Tpit is a highly cell-restricted transcription factor that is only present in the two pituitary POMC-expressing lineages, the corticotrophs and melanotrophs. This protein activates the transcription of the proopiomelanocortin (POMC) gene and it has an important role in the late differentiation of the corticotrophs and in the maintenance of both corticotroph and melanotroph cells (Lamolet et al., 2001; Pulichino et al., 2003). POMC is processed into adrenocorticotropin (ACTH) by pro-convertase 1 (PC1) in anterior pituitary corticotrophs and into melanocyte-stimulating hormone (MSH) by $\mathrm{PC} 2$ in rodent and dog intermediate lobe melanotrophs (Seidah et al., 1999).

Tpit, also described as Tbx19, belongs to the T-box family of transcription factors that have a highly conserved DNA-binding domain in common, the T-box, and are present in all vertebrates (Yi et al., 1999). The canine Tpit gene is situated in chromosome 7 , contains 8 exons that codify a protein of 445 aminoacids, and is $93.5 \%$ identical to human TPIT and $90.8 \%$ identical to murine Tpit (Hanson et al., 2008).

Recently, several Tpit mutations leading to lossof-function have been reported in isolated neonatal cases of ACTH deficiency in humans, supporting the essential role of Tpit for corticotrophs terminal differentiation and POMC regulation (Lamolet et al., 2001; Pulichino et al., 2003; Atasay et al., 2004; Metherell et al., 2004; Pulichino et al., 2004; Drouin et al., 2007). Otherwise, Tpit gain-of-function mutations induce POMC expression in undifferentiated pituitary cells (Lamolet et al., 2001).

Given its pivotal role in corticotroph development, Tpit involvement in pituitary tumorigenesis has been investigated. Tpit somatic mutations studies performed in canine and human pituitary tumors cDNA shave showed negative results (Hanson et al., 2008). However, the mutation analysis of genomic DNA in a large sample of dogs of the same breed highly predisposed to hyperadrenocorticism has not been reported yet. The aim of this study was to investigate the presence of germline mutations in the coding region of the Tpit gene in Poodle dogs with ACTH-dependent hyperadrenocorticism.

\section{MATERIALS AND METHODS}

The study included 50 Poodle dogs, of which 33 were females, with a mean age of 8.7 \pm 2.8 years (ranging from 1.5 to 14 years) with ACTH-dependent hypercortisolism, presented to a Veterinary Teaching Hospital between January, 2007 and February, 2009. Among these 50 dogs, three cases had other affected familial members with ADHAC (Figure 1). A tentative diagnosis of HAC was based on the presence of clinical signs associated to hypercortisolism (polydipsiapolyuria, polyphagia, pendulous abdomen, dermatologic problems and anoestrus) and the results of haematological and biochemical analyses of blood and urinalysis. A low dose of dexamethasone suppression (LDDS) test was carried out in each case to confirm the diagnosis. ADHAC was confirmed on the basis of a bilateral symmetric appearance and enlargement of the adrenal glands and an increased plasmatic ACTH concentration (Behrend and Kemppainen, 2001; Gould et al., 2001; Peterson, 2007). Informed consent was obtained from the owners of all dogs.

The control group was comprised of 50 Poodle dogs, of which 32 were females, mean age of $9.4 \pm 2.8$ years (ranging from 6 to 16 years) with no evidence of adrenal disease, also presented to a Veterinary Teaching Hospital between March, 2008 and February, 2009, and also normal dogs owned by hospital employees and students. Adrenal disease was ruled out in each dog on the basis of history, physical examination, and biochemical analysis. Control dogs were matched to ADHAC dogs on the basis of age ( $\geq 6$ years old) and breed (100\% Poodles).

The LDDS test consisted of measuring cortisol levels before and 8 hours after dexamethasone (Azium, dexamethasone phosphate, 2mg/mL, Intervet - Shering Plough, Beaucouzé, 
France) administration $(0.01 \mathrm{mg} / \mathrm{kg} / \mathrm{IV})$. Failure to suppress cortisol concentration adequately 8 hours after dexamethasone (cortisol $\geq 1.4 \mu \mathrm{g} / \mathrm{dL}$; reference value $<1.0 \mu \mathrm{g} / \mathrm{dL})$ was considered compatible with hyperadrenocorticism. Serum cortisol concentrations for the dynamic endocrine test were performed (BET Laboratories, Rio de Janeiro, RJ, Brazil) using a commercial radioimmunoassay kit (CoatA-Count, Cortisol, Radioimmunoassay Kit, Diagnostic Products, Los Angeles, USA), previously validated for canine cortisol (Watson et al., 1993). The intra-assay coefficient variation for cortisol was less than $5.1 \%$ and the interassay was less than $6.4 \%$. Blood samples for the measurement of plasma ACTH were collected in ethylenediaminetetraacetic acid-coated (EDTA) tubes, centrifuged immediately and the plasma promptly stored in plastic tubes and frozen at $70^{\circ} \mathrm{C}$ until assay. Plasma ACTH concentrations were measured by immunoradiometric assay (IRMA) using a commercial kit (ELSA-ACTH, CIS Bio international, Gif Sur Yvette, France) at Hormone and Molecular Genetics Laboratory LIM/42, Hospital das Clínicas, Faculdade de Medicina, São Paulo University (FMUSP), Brazil. The ACTH intra-assay and inter-assay coefficients of variation were less than $6.1 \%$ and $5.3 \%$, respectively. Dogs with ADHAC were identified by unsuppressed basal ACTH plasma concentrations $(>17 \mathrm{pg} / \mathrm{mL})$.

Genomic DNA was harvested from EDTAanticoagulated blood obtained from 50 ADHAC and 50 control Poodle dogs using standardized protocols (Miller and Dykes et al., 1988). Genomic DNA was amplified through the reaction of chain polymerization (PCR) in an automatic Thermal Cycler (Applied Biosystems PCR System 9700, Foster City, CA), using specific primers to ensure the assessment of all coding areas of Tpit gene (Table 1). PCR reaction was performed on $2 \mu \mathrm{L}$ genomic DNA in a $50 \mu \mathrm{L}$ volume containing $200 \mu \mathrm{M}$ dNTPs, $0.5 \mathrm{mM}(20 \mathrm{pmol})$ of each primer, 1.5U Go TaqPolimerase (Promega), 5x PCR reaction buffer (Promega) with $1.5 \mathrm{mM} \mathrm{MgCl}_{2}$. The PCR programs consisted of an initial activation at $98^{\circ} \mathrm{C}$ for $5 \mathrm{~min}$ followed by 40 cycles of $45 \mathrm{~s}$ each at $98^{\circ} \mathrm{C}, 30 \mathrm{~s}$ at $50-54^{\circ} \mathrm{C}$ (annealing temperature depending on the primer), $1 \mathrm{~min}$ at $72^{\circ} \mathrm{C}$, followed by a final extension at $72^{\circ} \mathrm{C}$ for $5 \mathrm{~min}$. The products were visualized in $1.5 \%$ agarose gel containing ethidium-bromide.

Table 1. Forward (F) and reverse (R) primers for canine Tpit amplification, product size (bp) and annealing temperature $\left(\mathrm{T}_{\mathrm{a}}\right)$

\begin{tabular}{|c|c|c|c|}
\hline Primer & Sequence & Product size $(\mathrm{bp})$ & $\mathrm{T}_{\mathrm{a}}\left({ }^{\mathrm{o}} \mathrm{C}\right)$ \\
\hline 1F Tpit & 5' GAA CGC TTC TCC GCC AAG TTT 3' & 341 & 50 \\
\hline 1R Tpit & 5' CCT CTG AGT GAA GAA GGG CA 3' & & \\
\hline 2F Tpit & 5' GCC ACC CAG GGA TCC CCT 3' & 392 & 55 \\
\hline 2R Tpit & 5' GGA GAA GAG GCC GGT GAG GA 3' & & \\
\hline 3F Tpit & 5' TGG TTA TCA CCC CTG CTA CCA 3' & 232 & 52 \\
\hline 3R Tpit & 5' GTT TAC ACA CAC GCA GCC AC 3' & & \\
\hline 4F Tpit & 5' ACT AAT GCT TCT TGT CTT TG 3' & 122 & 50 \\
\hline 4R Tpit & 5' AGA AGA TTT TAC TGA CAT T 3' & & \\
\hline 5F Tpit & 5'CAG GAG CAA TAA GTG CAA GCC A 3' & 370 & 53 \\
\hline 5R Tpit & 5' TGT GGC CCA CCC AGT GTT CA 3' & & \\
\hline 6F Tpit & 5' CGA CAT TCC GTG TCG TTC ACA 3' & 328 & 51 \\
\hline 6R Tpit & 5' TAC ACC CAA GGG TTT AAT TA 3' & & \\
\hline 7F Tpit & 5' TGT GGC ATA TGG TTG ACA TGG TA 3' & 329 & 50 \\
\hline 7R Tpit & 5' ACC AAT GAG GAA GTT GCT GGA 3' & & \\
\hline 8F Tpit & 5' GTC AGG ACA GCT ATT GTA CGC T 3' & 515 & 50 \\
\hline 8R Tpit & 5' CCT GCC CTA GGA TCC TGC CT 3' & & \\
\hline
\end{tabular}

Primers were designed in a sequence that was derived from the canine boxer genomic DNA sequence available at the National Center for Biotechnology Information (NCBI) (http://www.ncbi.nlm.nih.gov/genome/seq/Blast Gen/BlastGen.cgi?taxid=9615). Eight pairs of intron-flanking primers were designed based on the intron/exon information using the Primer3 core program (http://frodo.wi.mit.edu/cgi_bin/primer3/ primer3_www.cgi) (Table 1). Amplification products were submitted for pre-enzyme purification, using the Exo-SAP commercial 
product containing Shrimp Alkaline Phosphatase and exonuclease I enzimes (Amersham Science, USB, Cleveland, Ohio, EUA) according to manufacturer as follow: $2 \mu \mathrm{L}$ of exosap to $5 \mu \mathrm{L}$ of PCR product at $37^{\circ} \mathrm{C}$ for $15 \mathrm{~min}$. The sequencing reaction was performed using the commercial product ABI PrismTMBigDye Terminator (Perkin Elmer, Foster City, CA, EUA) followed by biotreatment columns Centri-SEP (Princenton separations, Adelphia, NJ, USA). The items on this reaction were submitted to capillary electrophoresis in automatic ABI3100 Genetic Analyzer (Applied Biosystems, Foster City, CA, USA). The canine sample coding sequence for Tpit was compared with the normal dog sequence from Ensembl database (www.ensembl.org.com) under number ENSCAFT00000024243 which was derived from the NCBI contigNC_006589.

The allelic variant p.S343G found in exon 7 of the Tpit gene creates an enzyme MSP I cleavage. The WT sequence leads to one fragment of $329 \mathrm{bp}$ and the mutant leads to fragments of 82 and $247 \mathrm{bp}$. Enzymatic digestion reaction was performed on the entire control group in a $20 \mu 1$ volume containing $10 \mu \mathrm{l} \mathrm{PCR}$ product of exon 7 , $1 \mu \mathrm{l}$ Msp I enzyme, $2 \mu 1$ specific buffer, for $4 \mathrm{~h}$ at $37^{\circ} \mathrm{C}$. Digestion products were visualized in ethidium-bromide containing $4 \%$ agarose gel and DNA fragments were viewed in ultraviolet light using $1 \mathrm{~KB}$ molecular weight marker.

\section{RESULTS}

PCR assays were performed on DNA samples isolated from one hundred Poodle dogs, 50 with ADHAC and 50 control dogs. No Tpit mutation was found to be responsible for the Cushing's disease phenotype in our cohort.

The new single nucleotide polymorphism p.S343G was found in exon 7 of the Tpit gene at the same frequency in both ADHAC and control groups. This allelic variant is characterized by an exchange of adenine by guanine, in a heterozygous state, at position 1027 from the cDNA sequence, leading to a substitution of serine with glycine in codon 343 (p.S343G) (Figure 2). The exchange of serine (AGC) with glycine (GGC) alters amino acid physico- chemical properties, since serine is a polar amino acid (hydrophilic) and glycine is apolar (hydrophobic). However, S343G is located out of the T-box (Figure 3), a conserved DNA region which encodes the DNA binding domain and is not conserved among several species. The heterozygous allelic variation p.S343G was also found in $2 \operatorname{dogs}$ from the control group $(\mathrm{n}=$ $2 / 50$ ). In both groups the allelic and genotypic frequency of p.S343G was $2 \%$ and $4 \%$, respectively.

\section{DISCUSSION}

ACTH-dependent hyperadrenocorticism is the most common cause of endogenous hyperadrenocorticism in dogs, accounting for 80 to $85 \%$ of the cases (Behrend and Kemppainen, 2001; Feldman and Nelson, 2004). The high incidence of this disease in dogs, the high breed predisposition, especially in Poodles and the description of familial ADHAC (Scholten-Sloof et al., 1992; Stritzel et al., 2008) have heightened the attention to the molecular basis of Cushing's disease.

The Poodle was chosen for molecular studies because it is the breed which is most prone to HAC in several studies (Guptill et al., 1997; Feldman and Nelson, 2004; Peterson, 2007) and also because three of our patients presented affected familial members. One of our familial cases (case 2, family 1, Figure 1) developed ADHAC with only 1 year and 5 months of age. Until this study, only 5 dogs younger than 2 years of age have been reported with ADHAC (Feldman and Nelson; 2004). Most of the cases are older than 6 years, with an average age of 11 years (Ling et al., 1979; Guptill et al., 1997; Peterson, 2001; Feldman and Nelson, 2004). Similarly, in this series the patients' mean age was $8.7 \pm 2.8$ years, but seven dogs $(14 \%)$ were younger than 6 years.

In addition to our three familial cases, there are only two other case reports in veterinary literature describing familial Cushing's disease in dogs involving the Dandie Dinmont terrier and the wire-haired Dachshund (Scholten-Sloof et al., 1992; Stritzel et al., 2008). 
Germline mutation...

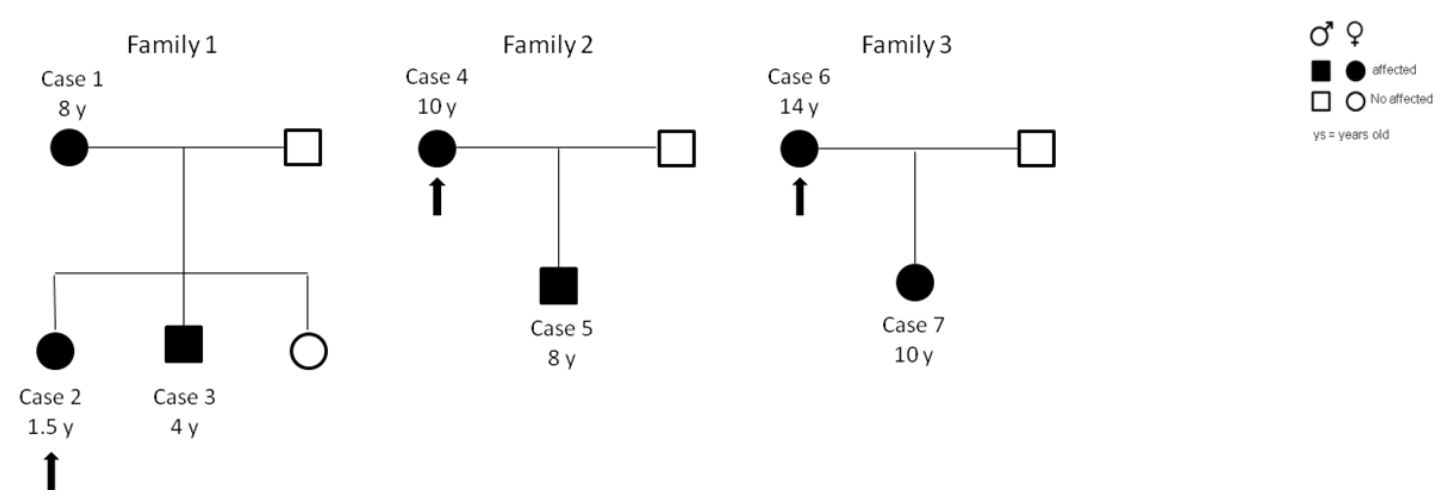

Figure 1. Pedigree of three families of Poodle dogs with ACTH-dependent hypercortisolism $(\mathrm{y}=$ years old).

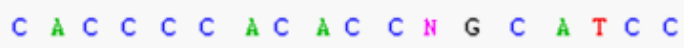

Exon 7

Ser343Gly

$\mathrm{AGC} / \mathrm{GGC}$

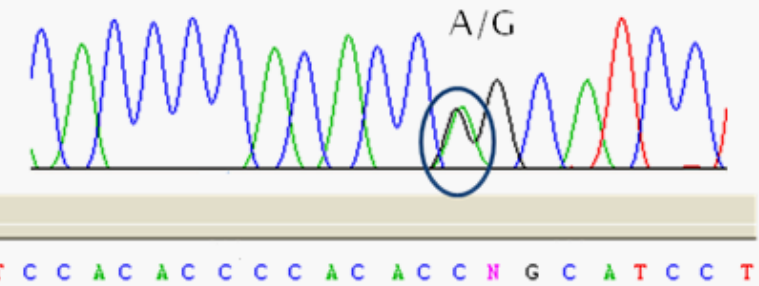

Fem, $12 y$

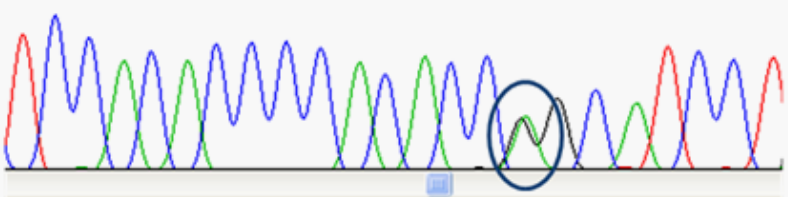

Fem, $10 y$

Figure 2.Heterozygous allelic variant, p.S343G, in the Tpit gene in two unrelated dogs with ACTHdependent hyperadrenocorticism. (Fem = female; $y=$ years old $)$.

\section{8 exons}

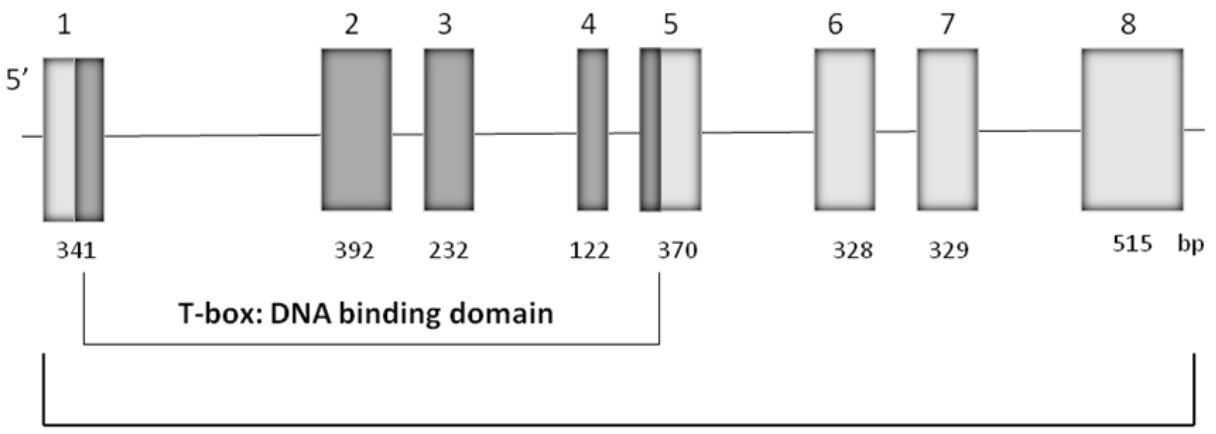

$24,09 \mathrm{~kb}$

Figure 3.The gray-boxed region corresponds to the T-box region of canine Tpit. 
In the pituitary gland, Tpit is an obligate transcription factor for the expression of the proopiomelanocortin (POMC) gene and for terminal differentiation of the corticotroph lineage. Tpit loss of function mutations have been reported in cases of early onset isolated corticotrophin deficiency (Lamolet et al., 2001; Pulichino et al., 2003; Atasay et al., 2004; Metherell et al., 2004; Pulichino et al., 2004; Drouin et al., 2007). Tpit knock out homozygous mutant mice (Tpit -/-) present almost complete loss of POMCexpressing cells in pituitary, intermediate lobe and adrenal glands hypoplasia and very low plasma ACTH and corticosterone levels (Pulichino et al., 2003).

It has been shown that Tpit mRNA is present and co-expressed with POMC mRNA in normal and adenomatous corticotroph cells in humans and in dogs, but it is most abundantly expressed in ACTH-secreting pituitary tumors causing Cushing's disease (Tateno et al., 2007; Hanson et al., 2008).

Considering the importance of Tpit in the development of corticotrophs and the transcription of POMC, we hypothesized that the Tpit gain-of-function mutations would be involved in the pathogenesis of ACTHdependent hyperadrenocorticism in Poodle dogs. However, no germline mutations were found in the Tpit from genomic DNA from 50 dogs with ADHAC. This finding is in agreement with two other studies that did not find Tpit somatic mutations in 8 human corticotrophmacroadenomas and in 23 canine ACTH-secreting pituitary tumors (Bucciarelli et al., 2005; Hanson et al., 2008). Nevertheless, we found the new polymorphism p. S343G in exon 7 of the Tpit in ADHAC dog groups as well as in the control group with the same frequency (4\%).

\section{CONCLUSIONS}

Germline mutation into the coding region of the Tpit gene is not involved in the pathogenesis of pituitary-dependent hyperadrenocorticism in this cohort of Poodle dogs. Future studies should include other genes to elucidate the genetic basis of Cushing's disease.

\section{REFERENCES}

ASA, S.L.; EZZAT, S. The cytogenesis and pathogenesis of pituitary adenomas. Endocr. Rev., v.19, p.798-827, 1998.

ATASAY, B.; AYCAN, Z.; EVLIYAOGLU, O. et al. Congenital early onset isolated adrenocorticotropin deficiency associated with a Tpit gene mutation. J. Pediatr. Endocrinol. Metab., v.17, p.1017-1020, 2004.

BEHREND, E.N.; KEMPPAINEN, R.J.; CLARK, T.P. et al. Diagnosis of hyperadrenocorticism in dogs: a survey of internists and dermatologists. J. Am. Vet. Med. Assoc., v.220, p.1643-1649, 2002.

BEHREND, E.N.; KEMPPAINEN, R.J. Diagnosis of canine hyperadrenocorticism. Vet. Clin. N. Am.: Small Anim. Pract., v.31, p.9851003, 2001.

BUCCIARELLI, L.G.; PECORI GIRALDI, F.; CAVAGNINI, F. No mutations in Tpit, a corticotroph-specific gene, in human tumoral pituitary ACTH-secreting cells. J. Endocrinol. Invest., v.28, p.1015-1018, 2005.

DROUIN, J.; BILODEAU, S.; VALLETTE, S. Of old and new diseases: genetics of pituitary ACTH excess (Cushing) and deficiency. Clin. Genet., v.72, p.175-182, 2007.

FELDMAN, E.C.; NELSON, R.W. Canine and Feline Endocrinology and Reproduction, 3.ed. Philadelphia: W.B.Saunders, 2004.1089p.

GOULD, S.M.; BAINES, E.A.; MANNION, P.A. et al. Use of endogenous ACTH concentration and adrenal ultrasonography to distinguish the cause of canine hyperadrenocorticism. J. Small Anim. Pract., v.42, p.113-121, 2001.

GUPTILL， L.; SCOTT-MONCRIEFF， J.C.; WIDMER, W.R. Diagnosis of canine hyperadrenocorticism.Vet. Clin. N. Am.: Small Anim. Pract., v.27, p.215-235, 1997.

HANSON, J.M.; MOL, J.A.; LEEGWATER, P.A. et al. Expression and mutation analysis of Tpit in the canine pituitary gland and corticotroph adenomas. Domest. Anim. Endocrinol., v.34, p.217-222, 2008. 
LAMOLET, B.; PULICHINO, A.M.; LAMONERIE, T. et al. A pituitary cellrestricted $\mathrm{T}$ box factor, Tpit, activates POMC transcription in cooperation with Pitx homeoproteins. Cell, v.104, p.849-859, 2001.

LING, G.V.; STABENFELDT, G.H.; COMER, K.M. et al. Canine hyperadrenocorticism: pretreatment clinical and laboratory evaluation of 117 cases. J. Am. Vet. Med. Assoc., v.174, p.1211-1215, 1979.

METHERELL, L.A.; SAVAGE, M.O.; DATTANI, M. et al. Tpit mutations are associated with early-onset, but not late-onset isolated ACTH deficiency. Eur. J. Endocrinol., v.151, p.463-465, 2004.

MILLER, S.A.; DYKES, D.D.; POLESKY, H.F. A simple salting out procedure for extracting DNA from human nucleated cells. Nucleic Acids Res., v.16, p.1215, 1988.

PETERSON, M.E.; KRIEGER, D.T.; DRUCKER, W.D. et al. Immunocytochemical study of the hypophysis in 25 dogs with pituitary-dependent hyperadrenocorticism. Acta Endocrinol., v.101, p.15-24, 1982.

PETERSON, M.E. Medical treatment of canine pituitary-dependent hyperadrenocorticism (Cushing's disease). Vet. Clin. N. Am.: Small Anim. Pract., v.31, p.1005-1014, 2001.

PETERSON, M.E. Diagnosis of hyperadrenocorticism in dogs. Clin. Tech. Small Anim. Pract., v.22, p.2-11, 2007.

PULICHINO, A.M.; LAMOLET, B.; VALLETTE-KASIC, S. et al. Tpit-/-NeuroD1-/mice reveal novel aspects of corticotroph development. Endocr. Res., v.30, p.551-552, 2004.
PULICHINO, A.M.; VALLETTE-KASIC, S.; COUTURE, C. et al. Human and mouse Tpit gene mutations cause early onset pituitary ACTH deficiency. Genes Dev., v.17, p.711-716, 2003.

SCHOLTEN-SLOOF, B.E.; KNOL, B.W.; RIJNBERK, A. et al. Pituitary-dependent hyperadrenocorticism in a family of Dandie Dinmont terriers. J. Endocrinol., v.135, p.535542, 1992.

SEIDAH, N.G.; BENJANNET, S.; HAMELIN, J. et al. The subtilisin/kexin family of precursor convertases. Emphasis on PC1, PC2/7B2, POMC and the novel enzyme SKI-1. Ann. N. Y. Acad. Sci., v.885, p.57-74, 1999.

STRITZEL, S.; MISCHKE, R.; PHILIPP, U. et al. Familial canine pituitary-dependent hyperadrenocorticism in wirehaired Dachshunds. Berl. Munch. Tierarztl. Wochenschr., v.121, p.349-358, 2008.

TATENO, T.; IZUMIYAMA, H.; DOI, M. et al. Differential gene expression in ACTH -secreting and non-functioning pituitary tumors. Eur. J. Endocrinol., v.157, p.717-724, 2007.

WATSON, A.D.; CHURCH, D.B.; EMSLIE, D.R. Plasma cortisol concentrations in dogs given cortisone or placebo by mouth. Res. Vet. Sci., v.55, p.379-381, 1993.

YI, C.H.; TERRETT, J.A.; LI, Q.Y. et al. Identification, mapping, and phylogenomic analysis of four new human members of the Tbox gene family: EOMES, TBX6, TBX18, and TBX19. Genomics, v.55, p.10-20, 1999. 